\title{
SEROLOGICAL RESULTS OF MVV AND CAEV ANTIBODIES IN SAMPLES COLLECTED FROM SHEEP AND GOAT FLOCKS OF ROMANIA
}

\section{Dan Alexandru Enache ${ }^{1}$, Stelian Baraitareanu ${ }^{2}$, Marius Dan ${ }^{3}$, Maria Rodica Gurau ${ }^{4}$, Camelia Nuţiu $^{5}$, Camelia Sarbu ${ }^{6}$, Doina Danes ${ }^{7}$}

\begin{abstract}
:
INTRODUCTION: Maedi-Visna (MV) and Caprine Arthritis Encephalitis (CAE) are specific diseases of small ruminants caused by lentiretroviruses. These diseases are not a public health concern but they are important due to their economic impact.

OBJECTIVES: The aim of this study is to analyse the results of the serological screening for MVV and CAEV antibodies in samples collected from small ruminants farms located in 14 Romanian counties and the proximity of Bucharest city.

METHODS: The samples were analysed by indirect ELISA, using a commercial diagnosis kit. We investigated 702 serum samples in 160 iELISA tests: 148 pools (2-5 samples/pool) and 12 individual animals.

RESULTS: We noticed $27.50 \%$ positive samples that confirm the exposure to MVV and CAEV viruses of small ruminants, but the confirmation is requesting investigation using molecular biology tools or other serological techniques.

CONCLUSION: A reliable picture over the SRLV infections could underlie a national program for monitoring.
\end{abstract}

UDC Classification: 616.9, DOI: 10.12955/cbup.v7.1444

Keywords: Maedi-Visna; Caprine Arthritis Encephalitis Virus; serology; lentivirus; Retroviridae.

\section{Introduction}

Small ruminant disease surveillance and diagnostics are two major activities of the Romanian veterinary services and research. Recent epidemiological studies have targeted zoonotic or emerging infectious diseases whose epidemiological situation is not fully known (Hotea et al., 2016; Daneş et al., 2016; Tilibasa \& Darabus, 2016; Baraitareanu et al., 2018). Also, Maedi-Visna (MV) and caprine arthritis and encephalitis (CAE) are economically important diseases of sheep and goats whose prevalence must be better known. MV and CAE are specific diseases of small ruminants caused by MV virus (MVV) and CAE virus (CAEV) (de Andres et al., 2005; Leroux et al., 2010; Cruz et al., 2013; Sanjose et al., 2015; Danes et al., 2016). These viruses belong to the Retroviridae family, Lentivirus genera, and they share a similar viral structure (Minguijon et al., 2015) and high genetic variability (Brinkhof, 2008; Herrmann-Hoesing, 2010). Small ruminant lentiviruses (SRLVs) were classified into 5 genotypes and several subtypes (Shah et al., 2004; Deubelbeiss et al., 2014; Daneş et al., 2016; Olech et al., 2019).

MV and CAE are not of public health concern but they are quite important because they can decrease productions. Some susceptible animals do not express any clinical sign following the viral exposure, but some could exhibit a respiratory form with interstitial pneumonia (Maedi) or a neurological form with progressive inflammatory disease of the central nervous system (Visna). Also, sheep and goats could be affected by inflammatory processes (located in joints and/or mammary gland) (Grego et al., 2007; Gomez-Lucia et al., 2018). The clinical signs are: coughing, lameness, weight loss and failures to mount (Hamza \& Ozkan, 2017). SRLV, having a very long period of incubation (even up to 2-3 years), the clinical signs can appear very late or not at all (Herrmann-Hoesing, 2010).

\footnotetext{
${ }^{1}$ Faculty of Veterinary Medicine, University of Agronomic Science and Veterinary Medicine of Bucharest, Romania; enachedan1990@yahoo.com

${ }^{2}$ Faculty of Veterinary Medicine, University of Agronomic Science and Veterinary Medicine of Bucharest, Romania; stelianbaraitareanu@ fmvb.ro

${ }^{3}$ Institute for Control of Biological Products and Veterinary Medicines, Bucharest, Romania;

dan.fmarius@yahoo.com

${ }^{4}$ Faculty of Veterinary Medicine, University of Agronomic Science and Veterinary Medicine of Bucharest, Romania; otelea_maria@yahoo.com

${ }^{5}$ Sanitary Veterinary and Food Safety Directorate of Mureş County, Romania; camelianutiu2001@yahoo.co.uk

${ }^{6}$ Sanitary Veterinary and Food Safety Directorate of Alba County, Romania; camyyss@yahoo.com

${ }^{7}$ Faculty of Veterinary Medicine, University of Agronomic Science and Veterinary Medicine of Bucharest, Romania; danes.doina@gmail.com
} 
Despite the viral susceptibility of all breeds to SRLVs, the clinical expressions observed is quite variable. While asymptomatic Karakul sheep imported to Iceland never developed any clinical sign (Torsteinsdóttir et al., 1992), some breeds seem to be more susceptible such as: Texel, Border Leicester, Finnish landrace, Assaf (Leginagoikoa et al., 2006; Muz et al., 2013). Other breeds tend to be more resistant such as: Columbia, Rambouillet, and Suffolk (Muz et al., 2013). In goats, Saanen and Toggenburg breeds seem to be more susceptible while Bedouin Black could be resistant to the CAEV infection under natural conditions (Rowe et al., 1992; Perk, 1995).

SRLVs could cross the species barrier and they can affect both sheep and goats (Peterhans et al., 2004). They should be considered specific lentiviruses for small ruminants, considering the other potential imminent source of infection: the wild ruminants (Sanjose et al., 2016). The following ones can be mentioned as susceptible: Ovis aries, Capra aegagrus hircus, Capra ibex, Ovis gmelinii, Oreamnos americanus, Ovis orientalis, and Ovis aries musimon (Denner, 2007; Guiguen et al., 2000; Leroux et al., 2010; Ramirez et al., 2013; Sanjose et al., 2016).

SRLVs transmission can be accomplished under the following conditions: direct contact (Leginagoikoa et al., 2006; Pisoni et al., 2007; Pérez et al., 2010), feeding with infected colostrum/milk (Mdurvwa et al., 1994; Leginagoikoa et al., 2006; Villoria et al., 2013; Junkuszew et al., 2016; Yang et al., 2017) or feeding on an infected pasture (Gufler, 2004; Gufler et al., 2007). The sexual transmission is not excluded (Al Ahmad et al., 2005; Lamara et al., 2013).

One of the most important problems regarding the diagnosis of SRLVs infection is what type of method to choose, and the most convenient way is to appeal to a serological technique: AGID (agar gel immunodiffusion), ELISA (enzyme-linked immunosorbent assay) or WB (western blotting) (OIE, 2017). Standard PCR should be performed when the serology results are not enough for a proper result, even when it is about seronegative animals or seropositive animals. In addition, sequencing PCR products can be useful to perform phylogenetic analyses (Sanjose et al., 2016; Sanchez et al., 2016; Panneum \& Rukkwamsuk, 2017; Kokawa et al., 2017; Yang et al., 2017). The prevalence tends to be higher in the countries which adopted the system of feeding lambs and/or kids with colostrum/milk from a tank. This practice could enhance the transmission (de la Concha-Bermejillo, 1997). All the genotypes, subtypes and recombinant SRLV viruses could contribute to a wider spectrum of cell and host tropism (Sanjose et al., 2016). SRLV seroprevalence is still a challenge that most countries in the world have to confront with. National programs should be implemented to reduce the seroprevalence in every country as, for example, Switzerland did: it began such a programme in 1980s exclusively on goats. The programme became mandatory 8 years later and the results did not delay. The seroprevalence decreased from $60-80 \%$ to less than $1 \%$ and the clinical cases of arthritis completely disappeared (Blatti-Cardinaux, 2016). Such programs have been successfully enforced in many countries (Rowe \& East, 1997). The viruses have been eliminated by culling the seropositive subjects and replacing them with seronegative animals (Sihvonen et al., 2000; Peterhans et al., 2004), if possible, from SRLVs free flocks or even areas. The antibody responses could fluctuate during the first 6 months of infection (Larsen et al., 1982) and it is quite necessary to perform regular serological tests and strict control measures as proper choice in order to eradicate the infection in a short period of time (Pérez et al., 2010; Rachid et al., 2013).

The present survey aimed to underline the results of MVV and CAEV seroprevalence in different Romanian sheep and goat flocks from January 2017 to March 2018.

\section{Material and Methods}

702 serum samples were analysed (Table 1) from five Romanian county clusters (Figures 1) by using a method described in a previous study (Enache et al., 2017). Briefly, from each subject 3-5 ml of blood was collected, in sterile conditions, from the jugular vein. The samples were stored $2-3 \mathrm{~h}$ at the room temperature and $24-48 \mathrm{~h}$ at $4^{\circ} \mathrm{C}$. The initial collection tubes were processed by centrifugation 1200 $1500 \mathrm{rpm} / 15-20 \mathrm{~min}$ and serum samples were transferred in sterile Eppendorf tubes. All the serum samples were stored at $-20^{\circ} \mathrm{C}$ until the serological investigation. The serological examination was done for 148 pools ( $2-5$ samples/pool) and 12 individual animals provided by farms located in 14 Romanian counties and the proximity of Bucharest city (Table 2). All samples were tested using an iELISA commercial kit (IDEXX CAEV/MVV Total Ab Test, Switzerland) according to the manufacturer's instructions. 
Table 1: Demographic information of the small ruminants included in survey

Source: Authors

\begin{tabular}{|c|c|c|c|c|}
\hline \multirow{2}{*}{ Samples } & \multicolumn{2}{|c|}{ Adults } & \multirow{2}{*}{ Young } & Total \\
\cline { 2 - 3 } & Females & Males & & \\
\hline Sheep & 483 & 113 & 11 & 607 \\
\hline Goats & 89 & 5 & 1 & 95 \\
\hline Total & 572 & 118 & 12 & 702 \\
\hline
\end{tabular}

Figure 1: Spatial distribution of the small ruminants included in survey

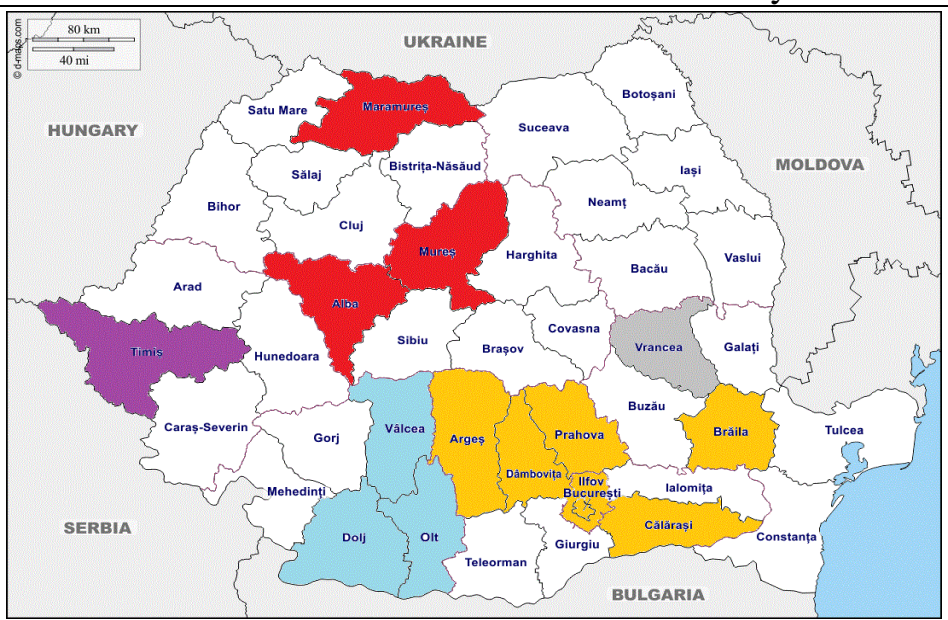

Legend: Blue - Oltenia, Red - Ardeal, Orange - Muntenia, Grey - Moldova, Purple - Banat

Source: Author; Map source: http://d-maps.com/m/europa/roumanie/roumanie25.gif)

Table 2: County distribution of iELISA tests (pools and individual samples) performed on small ruminants included in survey

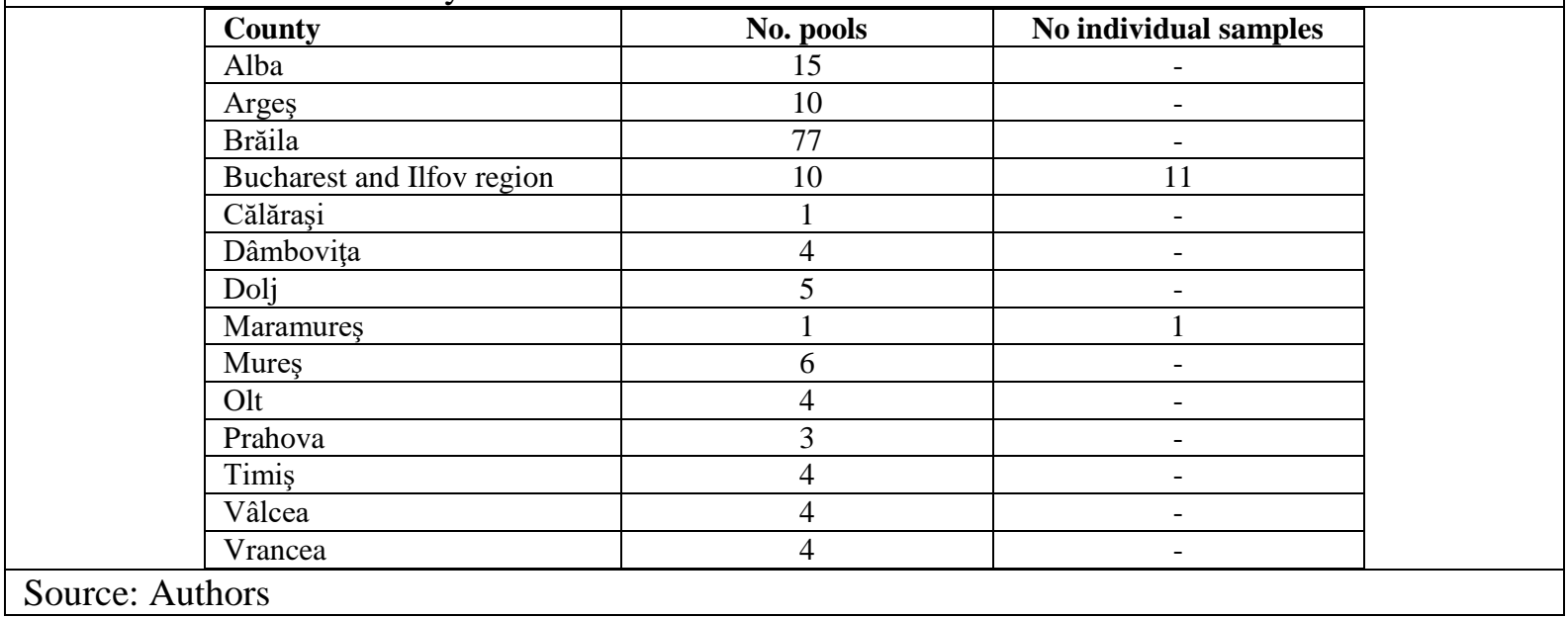

\section{Results and Discussion}

Out of 135 sheep iELISA tests, $22.96 \%(n=31)$ gave positive results, $4.44 \%(n=6)$ were suspect and $72.59 \%(\mathrm{n}=98)$ negative. While out of 25 goat tests, $52.00 \%(\mathrm{n}=13)$ gave positive results and $48.00 \%$ $(\mathrm{n}=12)$ were negative (Table 3, Figure 2).

Over all, the 160 sera samples from small ruminants tested by iELISA assay to detect CAEV/MVV antibodies provided $27.50 \%(\mathrm{n}=44)$ positive results, 3.75\% $(\mathrm{n}=6)$ suspect and $68.75 \%(\mathrm{n}=110)$ negative results (Figure 2).

The spatial distribution of the CAEV/MVV seropositive samples revealed that of 14 counties and the proximity of Bucharest area, we obtained at least one positive pool in 9 of these counties. In addition, these results were mostly located in small ruminant's populations from south and centre areas of Romania (Figure 3). 


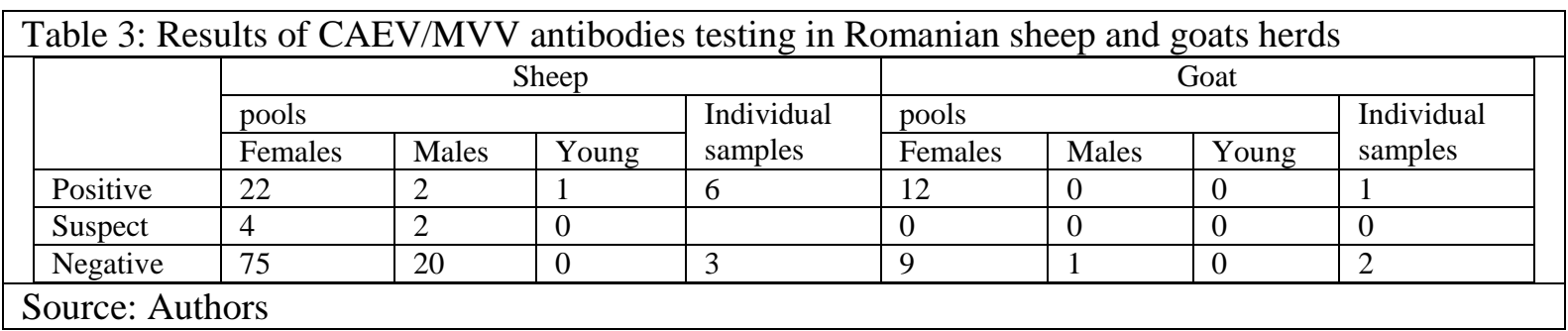

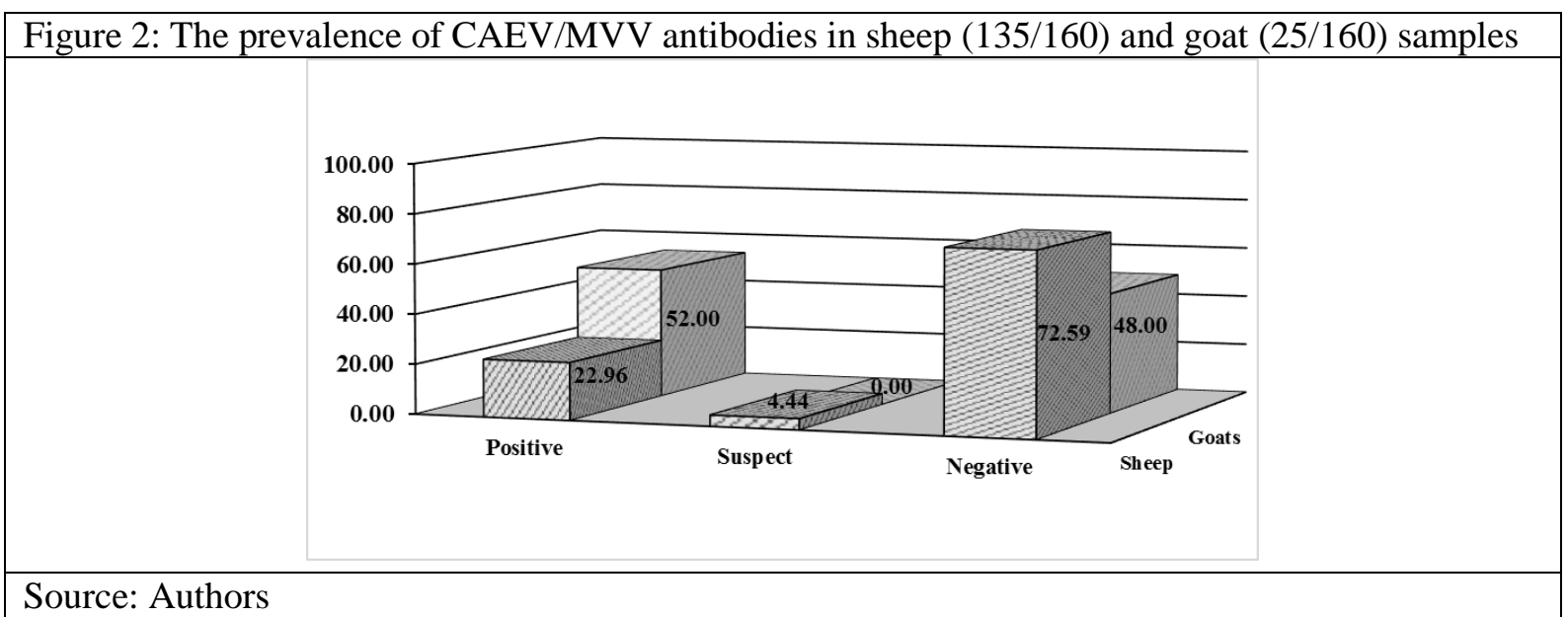

\begin{tabular}{|l} 
Figure 2: The prevalence of CAEV/MVV antibodies in small animal samples \\
\hline Source: Authors
\end{tabular}

The working methodology approached for this survey does not allow the calculation of epidemiological indicators, but provides valuable information on the spread of the SRLVs across Romania. In fact, the final results could be different due to the following reasons:

- the number of the investigated animals could be variable taking into consideration the animal production category, the counties of origin and, last but not least, the real possibility to collect samples from flocks;

- the individual seropositive animals could be modified because we suppose that a seronegative pool can "hide" one or more seropositive animals due to dilutions;

- the commercial diagnostic kit could have its own limits and we recommend to consider also other diagnostic tools;

- the seronegative young animals should be retested due to the seroconversion.

In this study, we identified six seropositive lambs in a farm located in the proximity of Bucharest city. Unfortunately, it was not possible to collect data regarding their mothers. Considering the infected colostrum/milk as a possible source of contamination, the status of their mothers would be useful to be investigated in order to reveal supplementary data, to support or not the supposition of the sexual transmission. We found, in our previous study seropositive animals from the same flock (Enache et al., 2017). 


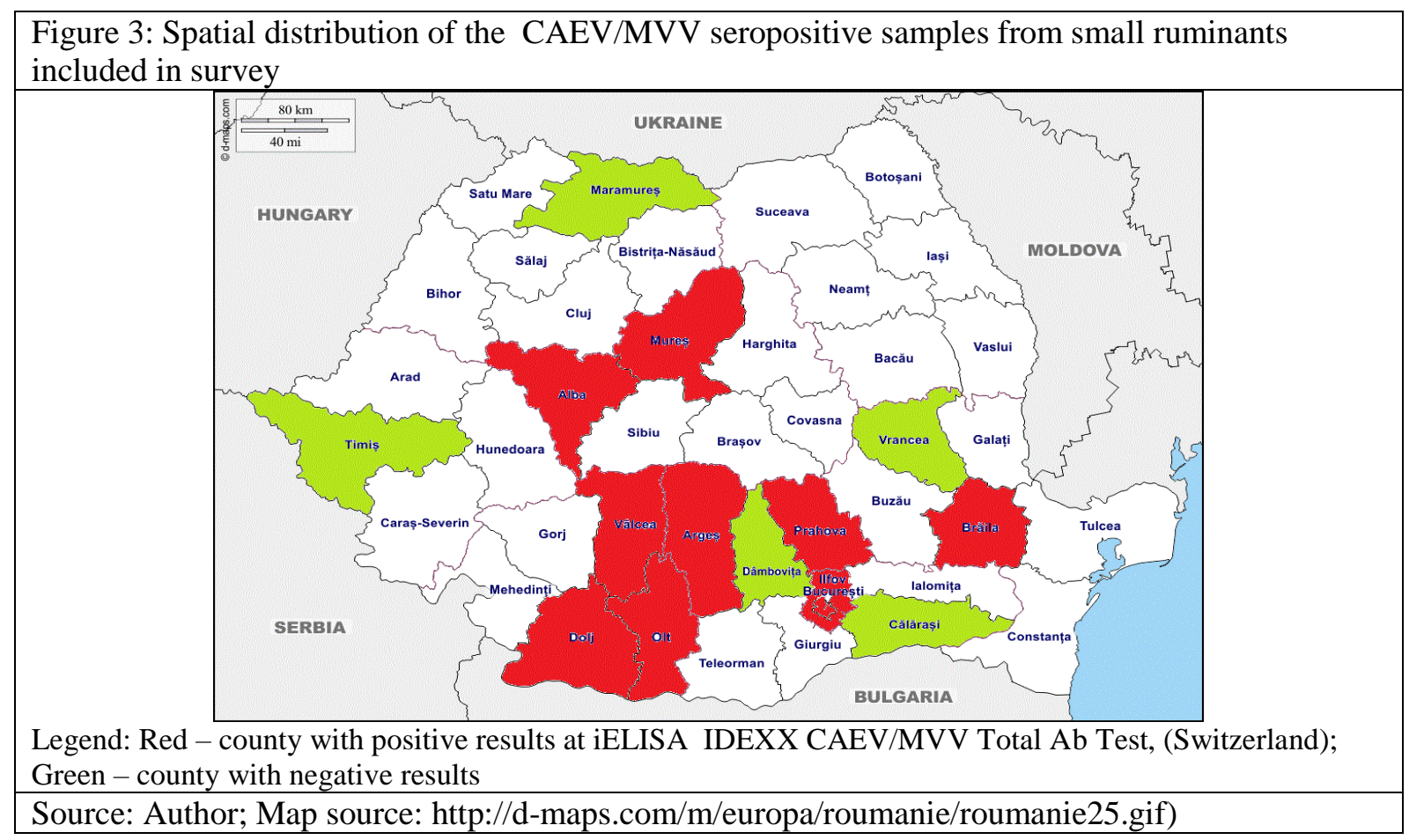

Based on these results, it become obvious the need for a more specific approach - using other different diagnostic tools - AGID or PCR as recommended by the World Organisation for Animal Health (OIE, 2017), to fully characterize the MV/CAE landscape in the Romanian flocks.

\section{Conclusion}

The obtained results confirm the exposure of the Romanian flocks to MVV or CAEV. The prevalence values found in both species is mirroring the velocity of the spread under natural conditions, without any interference, other than the breeding practices. The high level of the total prevalence must be considered as one of the "hidden" causes of the modest economic performances. A national control program to identify seropositive animals and to eliminate them from the flocks would be a first step in order to prevent the occurrence of outbreaks.

\section{References}

Al Ahmad, A., Fieni, F., Martignat, L., Chatagnon, G., Baril, G., \& Bouvier, F. (2005). Proviral DNA of caprine arthritis encephalitis virus (CAEV) is detected in cumulus oophorus cells but not in oocytes from naturally infected goats. Theriogenelogy, 64(7), 1656-1666

Baraitareanu, S., Ozdemir, Y.A., \& Dan, M., (2018). Serological detection of anti-Coxiella burnetii antibodies in Romanian small ruminants. Revista Romana de Medicina Veterinara, 28(3), 18-24

Blatti-Cardinaux, L., Pisoni, G., Stoffel M.H., Zanoni, R., Zahno, M.L., \& Bertoni, G. (2016). Generation of a molecular clone of an attenuated lentivirus, a first step in understanding cytopathogenicity and virulence. Virology, 487, 50-58

Brinkhof, J.M.A., van Maanen, C., Wigger, R., Peterson, K., \& Houwers D.J. (2008). Specific detection of small ruminant lentiviral nucleic acid sequences located in the proviral long terminal repeat and leader-gag regions using real-time polymerase chain reaction. Journal of Virological Methods, 147, 338-344

Cruz, J.C.M., Singh, D.K., Lamara, A. \& Chebloune, Y. (2013). Small Ruminant Lentiviruses (SRLVs) Break the Species Barrier to Acquire New Host Range, Viruses, 5, 1867-1884

Danes, D., Enache, D., Cobzariu, D., \& Baraitareanu, S. (2016). Etio-pathogenesis of small ruminant lentivirus infections: a critical review. Scientific Works. Series C. Veterinary Medicine, LXII(1), 59-64

de Andres, D., Klein, D., Watt, N.J., Berriatua, E., Tosteinsdottir, S., Blacklaws, B.A., \& Harkiss G.D. (2005). Diagnostic tests for small ruminant lentiviruses. Veterinary Microbiology, 107, 49-62

de la Concha-Bermejillo, A. (1997). Maedi-Visna and ovine progressive pneumonia. Veterinary Clinics of North America: Food Animal Practice, 13(1), 13-33

Denner, J. (2007). Transspecies transmissions of retroviruses: New cases. Virology, 369(2), 229-233

Deubelbeiss, M., Blatti-Cardinaux, L., Zahno, M.L., Zanoni, R., Vogt, H.R., Posthaus, H., \& Bertoni, G. (2014).

Characterization of small ruminant lentivirus A4 subtype isolates and assessment of their pathogenic potential in naturally infected goats. Virology Journal, 11, 65 
Enache, D., Baraitareanu, S., Dan, M., Gurău, M.R., Oţelea, F., Dobre, A., \& Daneş, D. (2017). Preliminary results of MVV and CAEV seroprevalence in Romanian sheep and goats. Scientific Works. Series C. Veterinary Medicine, LXIII, 1, 95-100 Gomez-Lucia, E., Barquero, N., \& Domenech, A. (2018). Maedi-Visna virus: current perspectives. Veterinary Medicine: Research and Reports, 9, 11-21

Grego, E., Bertolotti, L., Quasso, A., Profiti, M., Lacerenza, D., Muz, D., \& Rosati, S. (2007). Genetic characterization of small ruminant lentivirus in Italian mixed flocks: Evidence for a novel genotype circulating in a local goat population. Journal of General Virology, 88, 3423-3427

Gufler, H. (2004). CAEV: clinical and serological findings and the economical losses in a goat herd of "Passeirer Goat". Tierarztliche Praxis, 32, 263-268

Gufler, H., Gasteiner, J., Lombardo, D., Stifler, E., Krassnig, R., \& Baumgartner, W. (2007). Serological study of small ruminant lentivirus in goats in Italy. Small Ruminant Research, 73, 169-173

Guiguen, F., Mselli-Lakhal, L., Durand, J., Du, J., Favier, C., Fornazero, C., Grezel, D., Balleydier, S., Hausmann, E., \& Chebloune, Y. (2000). Experimental infection of Mouflon-domestic sheep hybrids with caprine arthritis-encephalitis virus. American Journal of Veterinary Research, 61, 456-461

Hamza, L.A., \& Ozkan, C. (2017). Serological investigation of Maedi-Visna in Sheep with Chronic Respiratory Disease in Erbil. Atatürk Üniversitesi Veteriner Bilimleri Dergisi, 12(3), 227-234

Herrmann-Hoesing, L.M. (2010). Diagnostic assays used to control small ruminant lentiviruses, Journal of veterinary diagnostic investigation, 22, 843-855

Hotea, I., Colibar, O., Ilie, M.S., Imre, M., Imre, K., Mederle, N., \& Darabus, G. (2016), Ovis aries and Felis silvestris catus toxoplasmic infection in Timis county, Romania. Revista Romana de Medicina Veterinara, 26(4), 33-36

Junkuszew, A., Dudko, P., Bojar, W., Olech, M., Osinski, Z., Gruszecki, T.M., Kania, M.G., Kuzmak, J., \& Czerski, G. (2016). Risk factors associated with small ruminant lentivirus infection in eastern Poland sheep flocks. Preventive Veterinary Medicine, 127, 44-49

Kokawa, S., Oba, M., Hirata, T., Tamaki, S., Omura, M., Tsuchiaka, S., Nagai, M., Omatsu, T., \& Mizutani, T. (2017). Molecular characteristics and prevalence of small ruminant lentiviruses in goats in Japan. Archives of Virology, 162(10), 3007-3015

Lamara, A, Fieni, F., Chatagnon, G., Larrat, M., Dubreil, L., \& Chebloune, Y. (2013). Caprine arthritis encephalitis virus (CAEV) replicates productively in cultured epididymal cells from goats. Comparative Immunology, Microbiology and Infectious Diseases, 36(4), 397-404

Larsen, H.J., Hyllseth, B., \& Krogsrud, J. (1982). Experimental maedi virus infection in sheep: cellular and humoral immune response during three years following intranasal inoculation. American Journal of Veterinary Research, 43(3), 384-389

Leginagoikoa, I., Juste, R.A., Barandika, J., Amorena, B., de Andres, D., Lujan, L., Badiola, J., \& Berriatua, E. (2006). Extensive rearing hinders Maedi- Visna Virus (MVV) infection in sheep. Veterinary Research, 37, 767-778

Leroux, C., Cruz, J.C. \& Mornex, J.F. (2010). SRLVs: a genetic continuum of lentiviral species in sheep and goats with cumulative evidence of cross species transmission. Current HIV Research, 8, 94-100

Mdurvwa, E.G., Ogunbiyi, P.O., Gakou, H.S., \& Reddy, P.G. (1994). Pathogenic mechanisms of caprine arthritisencephalitis virus. Veterinary Research Communications, 18, 483-490

Minguijon, E., Reina, R., Perez, M., Polledo, L., Villoria, M., Ramirez, H., Leginagoikoa, I., Badiola, J.J., Garcia-Marin, J.F., de Andres, D., Lujan, L., Amorena, B., Juste, R.A. (2015). Small ruminant lentivirus infections and diseases. Veterinary Microbiology, 181, 75-89

Muz, D., Oğuzoğlu, T.C., Rosati, S., Reina, R., Bertolotti, L., \& Burgu, I. (2013), First molecular characterization of visna/maedi viruses from naturally infected sheep in Turkey. Archives of Virology, 158, 559-570

OIE. (2017). Caprine arthritis/encephalitis and Maedi-Visna, Chapter 2.7.2/3, in Manual of Diagnostic Tests and Vaccines for Terrestrial Animals. Retrieved from: http://www.oie.int/fileadmin/Home/eng/Health_standards/tahm/2.07.0203_CAE_MV.pdf.

Olech, M., Murawski, M., \& Kuźmak, J. (2019). Molecular analysis of small-ruminant lentiviruses in Polish flocks reveals the existence of a novel subtype in sheep. Archives of Virology, 164, 1193-1198

Panneum, S., \& Rukkwamsuk, T. (2017). Diagnosis of Caprine Arthritis Encephalitis Virus infection in dairy goats by ELISA, PCR and Viral Culture. Polish Journal of Veterinary Sciences, 20(2), 347-353

Pérez, M., Biescas, E., de Andrés, X., Leginagoikoa, I., Salazar, E., Berriatua, E., Reina, R., Bolea, R., de Andrés, D., Juste, R.A., Cancer, J., Gracia, J., Amorena, B., Badiola, J. J., \& Luján, L. (2010). Visna/maedi virus serology in sheep: survey, risk factors and implementation of a successful control programme in Aragon (Spain). Veterinary Journal, 186, 221-225

Perk, K. (1995). Characteristics of ovine and caprine lentivirus infections. Leukemia, 9, 98-100

Peterhans, E., Greenland, T., Badiola, J., Harkiss, G., Bertoni, G., Amorena, B., Eliaszewicz, M., Juste, R.A., Krassnig, R., Lafont, J.P., Lenihan, P., Petursson, G., Pritchard, G., Thorley, J., Vitu, C., Mornex, J.F., \& Pépin, M. (2004). Routes of transmission and consequences of small ruminant lentiviruses (SRLVs) infection and eradication schemes. Veterinary Research, 35, 257-274

Pisoni, G., Moroni, P., Turin, L., \& Bertoni, G. (2007). Compartmentalization of small ruminant lentivirus between blood and colostrums in infected goats. Virology, 369(1), 119-130 
Rachid, A., Croise, B., Russo, P., Vignoni, M., Lacerenza, D., Rosati, S., Kuzmak, J., \& Valas, S. (2013). Diverse host-virus interactions following caprine arthritis-encephalitis virus infection in sheep and goats. Journal of General Virology, 94, 634642

Ramirez, H., Reina, R., Amorena, B., de Andres, D., \& Martinez, H.A. (2013). Small Ruminant Lentiviruses: Genetic Variability, Tropism and Diagnosis. Viruses, 5(4), 1175-1207

Rowe, J.D., \& East, N.E. (1997). Risk factors for transmission and methods for control of caprine arthritis-encephalitis virus infection. Veterinary Clinics of North America: Food Animal Practice, 13(1), 35-53

Rowe, J.D., East, N.E., Franti, C.E., Thurmond, M.C., Pedersen, N.C., \& Theilen, G.H. (1992). Risk factors associated with the incidence of seroconversion to caprine arthritis-encephalitis virus in goats on California dairies. American Journal of Veterinary Research, 53, 2396-2403

Sanchez, J.H., Martinez H.A., Garcia, M.M., Garrido, G., Gomez, L., Aguilar, J.A., de Andres, D.F., Reina, R., Ramirez, H. (2016). The presence of small ruminant lentiviruses in Mexican Pelibuey sheep. Theriogenelogy, 86(8), 1-5

Sanjose, L., Crespo, H., Blatti-Cardinaux, L., Glaria, I., Martinez-Carrasco, C., Berritua, E., Amorena, B., de Andres, D., Bertoni, G., \& Reina, R. (2016). Post-entry blockade of small ruminant lentiviruses by wild ruminants. Veterinary Research, 47, 1

Sanjose, L., Pinczowski, P., Crespo, H., Perez, M., Glaria, I., Gimeno, M., de Andres, D., Amorena, B., Lujan, L., \& Reina R. (2015). Diagnosing infection with small ruminant lentiviruses of genotypes A and B by combining synthetic peptides in ELISA. The Veterinary Journal, 204, 88-93

Shah, C., Huder, J.B., Boni, J., Schonmann, M., Muhlherr, J., Lutz, H. \& Schupbach, J. (2004). Direct evidence for natural transmission of small-ruminant lentiviruses of subtype A4 from goats to sheep and vice versa. Journal Virology, 78, 75187522

Sihvonen, L., Nuotio, L., Rikula, U., Hirvelä-Koski, V., \& Kokkonen, U., (2000). Preventing the spread of Maedi-Visna in sheep through a voluntary control programme in Finland. Preventive Veterinary Medicine, 47(3), 213-220

Tilibasa, E.M., \& Darabus, G. (2016), A short communication regarding first occurrence of bluetongue in Romania. Revista Romana de Medicina Veterinara, 26(2), 68-70

Torsteinsdóttir, S., Georgsson, G., Gísladóttir, E., Rafnar, B., Pálsson, P.A., \& Pétursson, G. (1992). Pathogenesis of central nervous system lesions in visna: Cell-mediated immunity and lymphocyte subsets in blood, brain and cerebrospinal fluid. Journal of Neuroimmunology, 41, 149-158

Villoria, M., Leginagoikoa, I., Luján, L., Pérez, M., Salazar, E., Berriatua, E., Juste, R.A., \& Minguijón, E. (2013). Detection of Small Ruminant Lentivirus in environmental samples of air and water. Small ruminant Research, 110, 155-160

Yang, W.C., Chen, H.Y., Wang, C.Y., Pan, H.Y., Wu, C.W., Hsu, Y.H., Su, J.C., \& Chan, K.W. (2017). High prevalence of caprine arthritis encephalitis virus (CAEV) in Taiwan revealed by large-scale serological survey. The Journal of Veterinary Medical Science, 79(2), 273-276 